\title{
Carbohydrate Reserves, Translocation, and Storage in Woody Plant Roots
}

\author{
Wayne H. Loescher, Thaddeus McCamant, and John D. Keller \\ Department of Horticulture and Landscape Architecture, Washington State University, \\ Pullman, WA 99164-6414
}

\begin{abstract}
All of the perennial organs of a woody plant may serve a storage function, but the highest concentrations of carbohydrate reserves are usually found in root tissues. These root reserves change dramatically throughout the year, decreasing rapidly with budbreak and early vegetative and reproductive development, and then increasing late in the growing season, usually after cessation of vegetative growth and fruit maturation. Accumulation of these reserves is very sensitive to late-season stresses and management practices, and decreased accumulation can profoundly affect a tree's performance the following year. These root reserves apparently play important and specific roles in supplying substrates for shoot respiration and growth, especially in woody species that flower and begin fruit development before substantial canopy development. Although phloem transport may be involved in root-to-shoot transport, considerable xylem transport occurs in some early flowering and fruiting species. Regulation of mobilization of root reserves remains unclear, but both gibberellins and auxins are possibly involved. Unfortunately, despite their apparent importance, mobilization, transport and the specific functions of root reserve carbohydrates are only superficially defined for any woody plant.
\end{abstract}

\section{IMPORTANCE OF CARBOHYDRATE RESERVES}

We are certain that reserves, especially stored carbohydrates, play essential roles in all trees. We know that, by the end of a growing season, tree roots will generally contain higher concentrations of carbohydrates and other reserves than any other tissues or organs. Nevertheless, we know very little about what specific roles these compounds play in tree survival, growth, and development. In addition, it is not clear what these materials are (Glerum, 1980), where they are stored, how they are mobilized or transported, or if they play any particular roles outside the roots. For most woody species, the specific roles of root carbohydrates and other root reserves in respiration during dormancy, in shoot expansion, in stem and root diameter growth, in new root length growth, in fruit set, and in flower bud initiation and development are almost completely unknown.

Reserves throughout woody plants are certainly important for several reasons. Winter survival depends on adequate reserves. The importance of respiration is clear. Buds often undergo some growth and development throughout the dormant season. In the seasonally dry tropics, many woody plants are deciduous, or nearly so, during the dry season (Opler et al., 1976). Yet, respiration continues, and reproductive development may occur in some species, e.g., Antiaris africana Engl. (Olofinboba, 1969), resulting in considerable reduction in and total reliance on reserves. In some temperate deciduous woody species, flowering also occurs before vegetative development, and the early stages of reproductive growth must be totally dependent on reserves. Most willows, poplars, birches, and maples are specific examples of temperate species in which anthesis and even substantial fruit development occur before leaf expansion and photosynthetic competence (Fowells, 1965).

Among deciduous fruits and nuts (the focus of this discussion), the importance of reserves to reproductive growth depends in part on the timing of flower and fruit development. Similar to willows and birches, stone fruits and pecans must rely on reserves for a while, since these species generally flower before canopy development (Westwood, 1978), although fruit development may occur after full leaf expansion. Other deciduous fruits may be less dependent on reserves. Apple leaves on fruiting spurs are, for example, nearly fully expanded before anthesis, and much of fruit development occurs late in the season, long after canopy development. Hansen (1971) reported that apple flowers depend on reserves only during their earliest stages of development, or until the first five or six leaves have formed. Once petals emerge from the sepals, photosynthesis from the leaves becomes the major source of carbohydrates for flower and fruit growth. Most of the apple reserves are apparently used in respiration rather than for new building materials (Hansen and Grausland, 1973), and, in young apple rootstocks, $<20 \%$ of $\left[{ }^{14} \mathrm{C}\right]$-labeled reserves assimilated in fall was fixed in new growth the following season (Hansen, 1967; Kandiah, 1979b). Tromp (1983) concluded that, while apple roots do certainly supply aboveground parts with carbohydrates early in the spring, it was doubtful whether such contributions are significant, and it was likely that reserves are used mostly in respiration.

It is, however, clear that reserves must be used in new leaf growth in all deciduous species. When nonbearing apple (Quinlan, 1969) and pecan (Lockwood and Sparks, 1978a) were fed ${ }^{14} \mathrm{CO}_{2}$ in the fall, radioactivity appeared in all new leaf and shoot growth the following spring. The same experiment on bearing pecan trees also showed that staminate and pistillate flowers used reserves (Lockwood and Sparks, 1978b). When bearing pecan shoots were fed ${ }^{14} \mathrm{CO}_{2}$, photosynthates were not exported until after pistillate anthesis, $\approx 3$ weeks after budbreak (Davis and Sparks, 1974), indicating that both root and secondary growth were entirely dependent on reserves until that time.

Although grapes are like apples and do not flower and begin cluster development until after several leaves have expanded, ${ }^{14} \mathrm{CO}_{2}$ labeling experiments showed that sugars manufactured in leaves in the fall (after harvest) and converted to starch in the wood and roots are the first carbohydrates used by new shoots the following spring (Kliewer and Leach, unpublished data, cited by Winkler et al., 1974). New grape shoots depend on these reserves until the first few leaves on the shoot are about half their full size, at which time they start exporting more photosynthate than they import (Hale and Weaver, 1962; Koblet, 1969, cited by Winkler et al., 1974). Therefore, it is clearly important that grape leaves remain active after harvest to establish carbohydrate reserves in root storage tissue for leaf growth and fruit cluster development the following spring.

\section{What are the carbohydrate reserves in roots?}

A tree may be $70 \%$ to $75 \%$ carbohydrates, but determining which of these play storage roles and contribute to early growth of respiration during dormancy presents some formidable analytical difficulties. Carbohydrate reserves generally include both soluble and insoluble substances, requiring several specific techniques for extraction and qualitative and quantitative assay. Roots present obvious sampling problems. Also, although the discussion here emphasizes carbohydrates, other compounds, especially nitrogenous reserves (Titus and Kang, 1982), play important and essential roles.

There is no evidence suggesting that roots contain unique carbohydrate reserves. There are, however, qualitative differences. For example, of the soluble carbohydrates, sucrose is the major photosynthetic product in many plants, the principal transportable carbohydrate, and the main storage sugar (ap Rees, 1984), but its presence is limited in woody roots. The hexose-reducing sugars, fructose and glucose, are commonly present in roots at higher concentrations than sucrose, whereas they are usually at lower concen- 
trations in above-ground parts. And, while both reducing and most nonreducing sugars like sucrose have routinely been detected and quantified in roots in the past, the methods used often did not detect sugar alcohols. Sugar alcohols, as nonreducing carbohydrates, are common constituents of many plants. Sorbitol in the Rosaceae, or more commonly mannitol in other families (e.g., the Oleaceae, Rubiaceae, Scrophulariaceae, and Apiaceae) may be the principal photosynthetic product, the major transport substance, and an important storage compound in leaves and other tissues (Lewis, 1984; Loescher, 1987), but sugar alcohols appear to be only minor components of roots. Failure to account for sugar alcohols, however, in plants now known to be major producers of these compounds, is a major defect in some older research and occasionally in more recent literature.

Many other soluble carbohydrates, such as inositol, xylose, rhamnose, maltose, trehalose, arabinose, ribose, mannose, and galactose, as well as the sucrose derivatives raffinose and stachyose, are now known to occur in low amounts in both roots and shoots. Among these, raffinose has been identified as a storage carbohydrate, particularly during dormancy in several tree fruits shoots and roots (Keller and Loescher, 1989; Lasheen and Chaplin, 1977). Fructans, fructose polymers of various sizes, are common in grasses and several other important taxa (Pollock, 1986), but evidence of their presence in deciduous fruit trees is lacking for either shoots or roots.

Starch is ubiquitous and usually the main insoluble storage carbohydrate in most above-ground woody plant tissues, but, in sweet cherry leaves, soluble carbohydrates, mainly sorbitol, accumulate more than starch (Roper et al., 1988). Wood ray parenchyma, however, in shoots, trunk, and especially roots often contain large amounts of starch (Keller and Loescher, 1989) and protein (Sauter et al., 1988), while only trace amounts of soluble carbohydrates are present, although poplar may be an exception (Bonicel et al., 1987).

Regarding other potential storage carbohydrates, it is questionable whether hemicelluloses play any roles as root reserves, despite work by Priestly (1962) and Kandiah (1979a). Susceptibility of these compounds to various extraction procedures will vary depending on the development of other crosslinks in the cell walls (Fry, 1986), which could confound interpretation of a role as storage compounds. Also, although these extracellular polysaccharides are known to be secondary carbohydrate reserves in endosperm of certain seeds (Halmer and Bewley, 1984), other work suggests that hemicellulose is not a storage material in the grapevine, since its level is not reduced by acute carbohydrate restriction resulting from defoliation (Winkler and Williams, 1938). Similarly, defoliation of apple (Proebsting, 1925) and severe topping of pecan (Smith et al., 1939) depleted starch, but not hemicellulose, leading these authors to conclude that hemicellulose was primarily structural in nature.

\section{Location of carbohydrate reserves}

The whole tree may be considered a storage organ, and storage carbohydrates are commonly found in all the perennial parts of the tree. Temperate trees follow a standard pattern of deposition and use of these carbohydrates throughout the plant and over the season (Kramer and Kozlowski, 1979). For example, deposition of starch, the primary nonstructural root storage carbohydrate, begins throughout the plant shortly after leaf expansion and usually reaches a peak after shoot growth ceases in maple (Wargo, 1979), ash (Seybold, 1969), poplar (Isebrands and Nelson, 1983; Nelson and Dickson, 1981), and mulberry (Yamashita, 1984, 1986). Starch deposition occurs primarily in roots after fruit ripening in apple (Faby and Naumann, 1986a; Kandiah, 1979a), sweet cherry (Keller and Loescher, 1989), and pecan (Smith et al., 1986).

For some deciduous fruit tree and vine crops, seasonal changes in nonstructural carbohydrates have been extensively characterized, especially in apple (Beattie, 1948; Chong, 1971; Chong and Taper, 1971a, 1971b; Grochowska, 1973; Hansen, 1967; Hansen and Grauslund, 1973; Hooker, 1920; Kandiah, 1979, 1979b; Loescher et al., 1982; Mochizuki and Hanada, 1956; Murneek, 1933; Priestley, 1960, 1964, 1981; Proebsting, 1925; Rao and Berry, 1940; Taper and Liu, 1969; Traub, 1927; Whetter and Taper, 1963) and in grape (Bains et al., 1981; Eifert and Eifert, 1963; Kliewer, 1965; Kliewer, 1967; Kliewer and Nassar, 1966; Marutyan, 1962; Pickett and Cowart, 1941; Scholefield et al., 1978; Winkler, 1929; Winkler and Williams, 1938; Winkler and Williams, 1945). Other species studied include peach (Breen, 1975; Dowler and King, 1966; Lasheen and Chaplin, 1977; Rohrbach and Luepschen, 1968; Rom and Ferree, 1985; Ryugo and Davis, 1959; Stassen et al., 1981), pear (Cameron, 1923; Gardner, 1929), pecan (Davis and Sparks, 1974; Smith and Waugh, 1938; Worley, 1973, 1979); persimmon (Archer, 1941); pistachio (Crane and Al-Shalan, 1977; Crane et al., 1976); plum (Breen, 1975; De Villiers and Meynhardt, 1972); prune (Braun et al., 1971; Davis, 1931), sour cherry (Anderson and Hooker, 1927); sweet cherry (Fischer, 1891; Beres, 1972; Keller and Loescher, 1989; Roper et al., 1988); and walnut (Ryugo et al., 1980). Unfortunately, roots have not always been considered, but these studies demonstrate the dynamic nature of nonstructural carbohydrates in most permanent parts of deciduous plants throughout the year. Generally, as growth resumes in the spring, carbohydrate reserves are depleted in shoots and roots, usually beginning before budbreak. After reaching a minimum, most tissues usually begin to accumulate reserves immediately. In some cases, this accumulation is interrupted during the period of fruit ripening (Roper et al., 1988). Total nonstructural carbohydrates (TNC) later reach a maximum at the time of leaf abscission. TNC remain unchanged or slowly decrease during the winter, after which the cycle repeats. The data for sweet cherry are just one example, and seasonal changes in TNC are shown in Fig. 1 (from Keller and Loescher, 1989).

As in other woody plants, the focus in various fruit crops has been on above-ground parts, where shoot bark tissues usually contain more soluble carbohydrates than wood, and where starch is most abundant in the wood (Crane and Al-Shalen, 1977; Crane et al., 1976; Dowler and King, 1966; Gardner, 1929; Kliewer, 1967; Proebsting, 1925). During the winter, although the totals may change only slightly, there may be considerable interconversion of starch and soluble carbohydrates, especially in shoot bark and wood tissues (Nelson and Dickson, 1981; Sauter, 1988), but not in roots (Keller and Loescher, 1989). Apple bark usually contains higher levels of total nonstructural carbohydrates than wood, but the total tree dry weight of wood exceeds that of bark, resulting in about equal amounts of these in bark and wood (Kandiah, 1979a). In sweet cherry, however, trunk wood, especially that more than several years old, contains few reserves in comparison to other above-ground tissues (Fig. 1). Consequently, the relative importance of trunk and shoot wood and bark varies with the species.

Although the whole tree may be involved in storage, evidence that roots play a special role is unclear. Nonetheless, regardless of species or flowering and fruiting behavior, the root system nearly always contains higher concentrations of nonstructural carbohydrates than any other portion of the tree, and therefore has been considered the main site of carbohydrate storage. Several kinds of data support this conclusion for apple (Abusrewil et al., 1983; Chong, 1971; Lockwood and Sparks, 1978a; Murneek, 1933; Priestley, 1960; Priestley, 1964), but seasonal studies of carbohydrate resources showed that the distribution between above- and belowground apple tissues remained constant, even though the total amount in the tree fluctuated. This and other similar data for apples have led to the conclusion that the root system should not be regarded as a special storage organ (Priestley, 1960; Tromp, 1983). Supporting this contention, $\approx 70 \%$ of the apple tree's dry weight may be in above-ground parts, and, although the concentrations are lower, these contain almost twice as much extractable carbohydrate on a whole-plant basis as below-ground parts (Priestley, 1960).

Nonetheless, seasonal changes in root carbohydrates in sweet cherries and other species suggest that roots play a distinct role in storage. Keller and Loescher (1989) have shown not only that root carbohydrate reserves are higher than in other storage tissues (totalling $20 \%$ or more of root dry weight), but also that root reserves do not substantially decrease until budbreak (Fig. 1). In contrast to roots, above-ground sweet cherry tissues begin to deplete carbohydrates in late winter, especially those nearest active sinks. Accumulation patterns also show that minimum carbohydrate content 


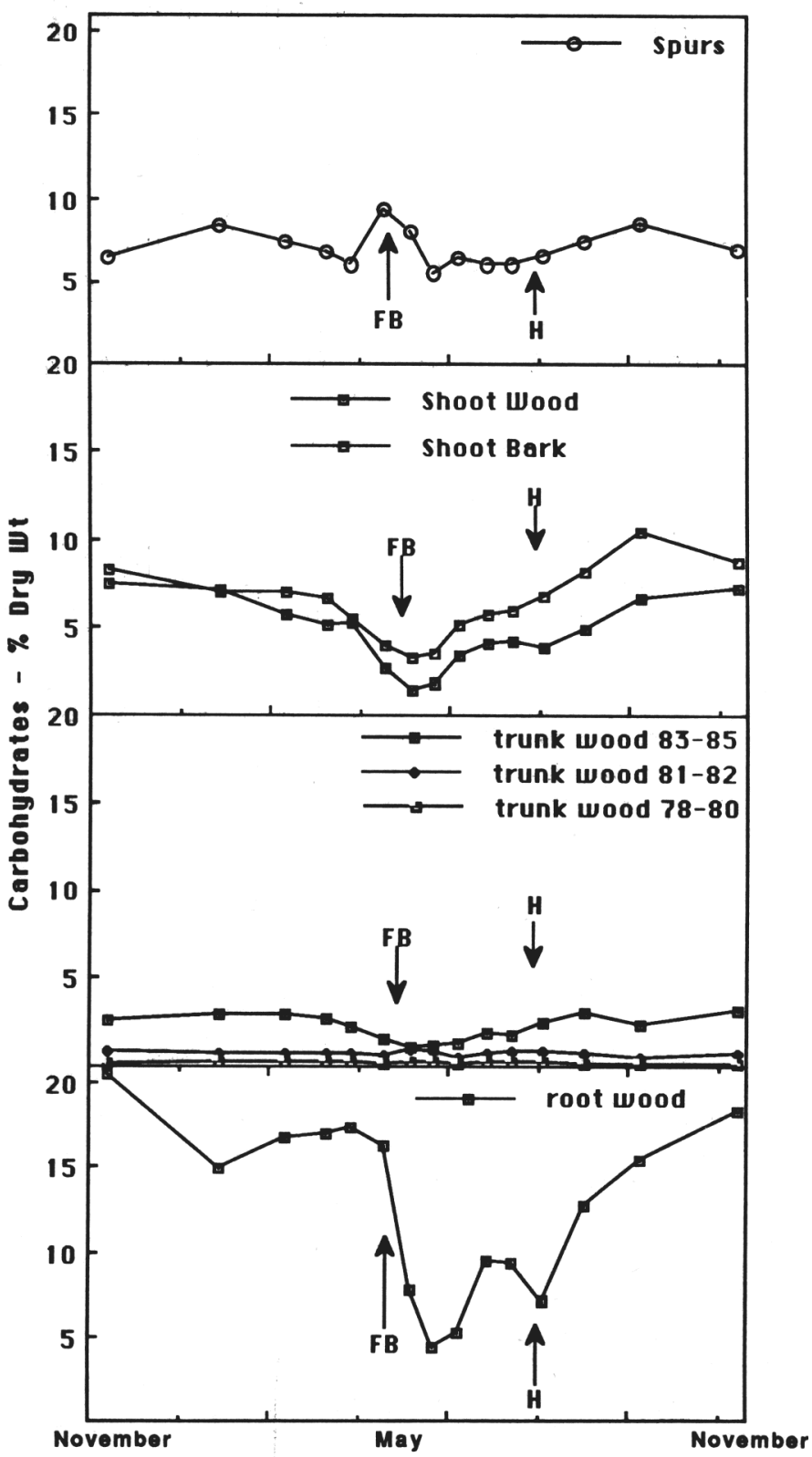

Fig. 1. Annual changes in total nonstructural carbohydrates in various organs of the sweet cherry (Prunus avium 'Bing' on 'Mazzard'). Data are condensed from Keller and Loescher (1989) and represent samples taken for the full year beginning in Nov. 1984. Trunk wood numbers refer to the years in which annual growth increments were added. Total nonstructural carbohydrates (TNC) include the soluble carbohydrates (sorbitol, sucrose, fructose, glucose, raffinose, and inositol) plus starch. $\mathrm{FB}=$ full bloom. $\mathrm{H}=$ fruit harvest.

of sweet cherry roots did not occur until after storage had begun in stem tissues (Fig. 1). Similar results were observed in grape (Winkler and Williams, 1945) and sugar maple (Wargo, 1979). Such differences in the use of root reserves may simply be due to proximity to active sinks (Kramer and Kozlowski, 1979), or reflect the effects of low soil temperatures early in the growing season. McCamant (1988) has, for example, shown that use of sweet cherry root reserves is highly temperature-dependent, with little or no decrease in these reserves at temperatures $<10 \mathrm{C}$.

\section{Environmental, developmental, and management effects on root reserves}

An alternative approach to identifying the specific role(s) of root reserves is to look at responses to environmental, developmental, and management factors. Unfortunately, responses to environmental stresses can be complex. For example, slight or transient droughts, not completely inhibitory to photosynthesis, may inhibit shoot growth, and, through reallocation of photosynthates, actually increase carbohydrate reserves (Bradford and Hsiao, 1982). Other stresses may have similar effects (Wagner and Evans, 1985). We have found similar results in sweet cherry, where deficit irrigation had little effect on photosynthesis, but carbohydrate reserves increased, especially in roots (Rom and Loescher, unpublished data).

Temperature may affect use of reserves in several ways. Respiration is important in the dormant season, even in temperate environments, and, because respiration increases exponentially with temperature, maintenance costs may ultimately affect productivity (Kramer and Kozlowski, 1979; Waring, 1987). Low temperatures not only slow respiration, but also influence carbohydrate reserves qualitatively. For example, high sorbitol levels in tracheal sap of apple correspond with the lowest temperatures on a monthly or even a daily basis (Raese et al., 1978; Williams and Raese, 1974; Hansen and Grauslund, 1973, 1978; Ichiki and Yamaya, 1982). At the same time, starch decreases in parenchyma cells, suggesting starch-sorbitol interconversions. In all these cases, however, sorbitol concentration in apple xylem dropped weeks before budbreak (Williams and Raese, 1974). Although the timing is different, similar qualitative changes have been found in sucrose-translocating trees, e.g., sugar maple (Cortes and Sinclair, 1985) and poplar (Sauter and Kloth, 1987; Sauter, 1988).

In sweet cherry, temperature clearly affected use of root starch reserves with little or no decline in starch below 10C (McCamant, 1988). Such temperature-dependent declines in root starch were also correlated with top growth (Fig. 2), and occurred only as long as growing buds were present (topped or debudded trees showed no decline). Continued top growth clearly stimulated hydrolysis and transport of root reserves. This relationship also suggests that use of root reserves primarily involves transport and not respiration; otherwise, root starch levels would have also declined at higher temperatures in the absence of buds or top growth. Although one study has shown that low root temperatures slow apple shoot growth and perhaps nitrogen uptake (Tromp and Ovaa, 1984), there are very few other data on the effects of root temperatures on carbohydrate use and transport in woody plants.

Fruiting often decreases carbohydrate reserves, but there is little evidence that roots are especially affected in fruit trees. In prune, for example, starch in bark, wood, spurs, roots, and trunk was higher in nonbearing trees than bearing ones throughout the year, except at the time of the first growth flush (Davis, 1931). Starch decreased just before harvest in 2-year-old bark and wood and spurs of bearing trees, but to a lesser extent, or not at all, in nonbearing trees. In apple spurs from nonbearing trees, starch was significantly higher than in those from bearing trees during the summer months for 3 consecutive years (Grochowska, 1973). In mandarin, starch levels in leaves, branches, trunk, and roots were at least twice as high in nonbearing than bearing trees. The differences were especially large in roots (Goldschmidt and Golomb, 1982). These and similar reports (Archer, 1941; Crane and Al-Shalan, 1977; Hooker, 1920; Jones et al., 1970; Lenz and Küntzel, 1974; Ryugo et al., 1977) indicate that the presence of reproductive sinks decreases nonstructural carbohydrates stored in all vegetative tissues. Other studies, however, have shown equal or higher amounts of nonstructural carbohydrates in tissues of bearing compared to nonbearing trees (Crane et al., 1976; Smith et al., 1986; Wood and McMeans, 1981). Although fruiting slowed mid-season accumulation of reserves in nearly all above-ground tissues of the sweet cherry, there was no effect on roots, and, by the season's end, there were no differences due to fruiting in any tissue (Roper et al., 1988). The detection of treatment differences in many of these studies may be due to the way the results are expressed. For example, the percentage of sorbitol and sugars in roots of 2-year-old apple trees was higher in fruiting than nonfruiting trees (Hansen and Grauslund, 1978). But, the total root dry matter of fruiting trees was less than half that of nonfruiting trees, and hence the total amount of sorbitol and sugars was less in fruiting tree roots.

Despite the ambiguity of fruiting effects, removal of leaf and stem reserves through defoliation or pruning suggests a distinct role for root reserves. That removal of vegetative parts decreases veg- 


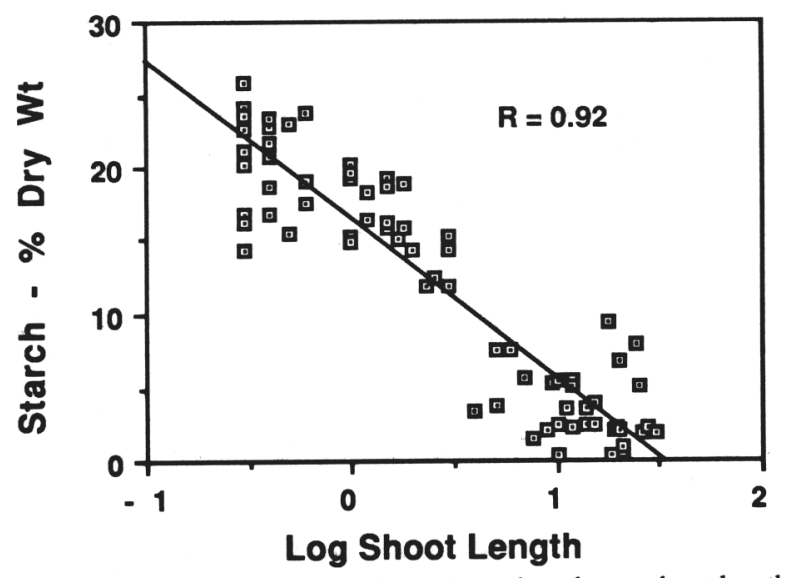

Fig. 2. Relationship between root wood starch and new shoot length of 1-year-old sweet cherry (Prunus avium 'Mazzard') seedlings taken from cold storage, planted in 3.8-liter pots, and grown at $18 \mathrm{C}$.

etative growth and the potential to produce future vegetative yield generally seems clear (Cannell, 1985). Summer pruning effects in apple (Sauré, 1987) and $\left[{ }^{14} \mathrm{C}\right]$-labeling in autumn in poplar (Isebrands and Nelson, 1983) also confirm the importance of autumn foliage for root growth and that roots gain sink strength as the season progresses. Late-season defoliation always results in smaller carbohydrate reserves, and the roots are the most sensitive storage organ to such treatment. In sugar maple, for example, late July defoliation resulted in a root starch content $1 \%$ of control, compared to $10 \%$ of control in shoot wood (Gregory and Wargo, 1985). In pecans, small roots also showed the greatest starch depletion after September defoliations (Worley, 1979). Regrowth in both these species can, however, replenish most of the reserves.

In sweet cherries, defoliation clearly reduced root starch reserves in November after leaf abscission (McCamant, 1988). Sweet cherries defoliated in August had the least amount of starch in all tissues, while trees defoliated at later dates had higher levels, increasing with later defoliation dates (Fig. 3). This pattern suggests, like regrowth in other species, that photosynthesis, even late in the season, is important for normal starch accumulation. Photosynthesis in October was surprisingly important, as the root starch of Octoberdefoliated trees was half that of the controls. As in sugar maple and pecan, sweet cherry root starch was the reserve most sensitive to defoliation. In August-defoliated trees, shoot wood starch concentrations were twice that of root wood, when normally root wood has more than twice the starch of the shoots. In October-defoliated trees, root starch was half the control, but shoot starch of the same trees was nearly the same as the controls.

Similar defoliation data indicate root reserves are critical to survival. In sweet cherry, as in sugar maple, early defoliation resulted in death of the tree the following year, although shoot reserves were relatively little affected compared to root reserves (Fig. 3). In addition, 1 month after bloom the following year, August- and September-defoliated sweet cherries had small, yellow leaves and poor fruit set (McCamant, 1988). October-defoliated trees did not show deficiencies, but did have smaller leaves and less overall growth. The yellow leaves on August and September treatments were probably due to nitrogen deficiencies, such as those documented in defoliated apple trees (Faby and Naumann, 1986b, 1986c). Some nitrogen deficiencies are expected, because metabolic nitrogen that could be remobilized in the leaves and transported to the bark and roots for storage is lost entirely when leaves are removed before normal abscission.

Alternatively, inadequate carbohydrate reserves in the roots could also create nitrogen deficiencies through a lack of carbohydrate substrates for new root growth. For example, heavy nitrogen fertilization had little effect in increasing the leaf nitrogen content of apple trees defoliated the previous summer (Faby and Naumann, 1986c). Root growth in pecans is believed to rely entirely upon reserves for the first 2 months of the growing season (Lockwood and Sparks, 1978a, 1978b), and defoliation severely inhibits root growth in apple trees (Head, 1969). Although October-defoliated sweet cherries did not show the same nutrient deficiencies of trees defoliated earlier in the season, and yet had less root starch than the controls, the lack of root reserves could still have been the main cause of nutrient deficiencies (McCamant, 1988). For example, Worley (1979) hypothesized a threshold level for reserve carbohydrates in pecans, below which no yield could be expected. A similar situation may exist in sweet cherry and other species, where the dramatic differences between early and late defoliation treatments suggest a probable threshold level of reserve carbohydrates for normal leaf development and nitrogen assimilation.

\section{Radioisotope labeling studies}

The best evidence for the role of roots in early season growth comes from labeling studies. Kandiah (1979b), Quinlan (1969), and Hansen and Grauslund (1973) all showed that, at budbreak, labeled carbohydrates from apple roots were translocated to the first formed leaves and also to flowers (Quinlan, 1969; Hansen and Grauslund, 1973). In pecan, Lockwood and Sparks (1978a, 1978b) found most of the label from root reserves in the first formed leaves, but also found the same reserves in leaves formed well after budbreak, as well as in male and female inflorescences. Similar data have already been mentioned for grape.

After terminal buds set in the late summer, the flow of photosynthates is primarily basipetal, e.g., in grape (Hale and Weaver, 1962), apple (Kandiah, 1979b; Quinlan, 1969), and pecan (Lockwood and Sparks, 1978a, 1978b). Such photosynthates are believed to become structural components (Lockwood and Sparks, 1978a,

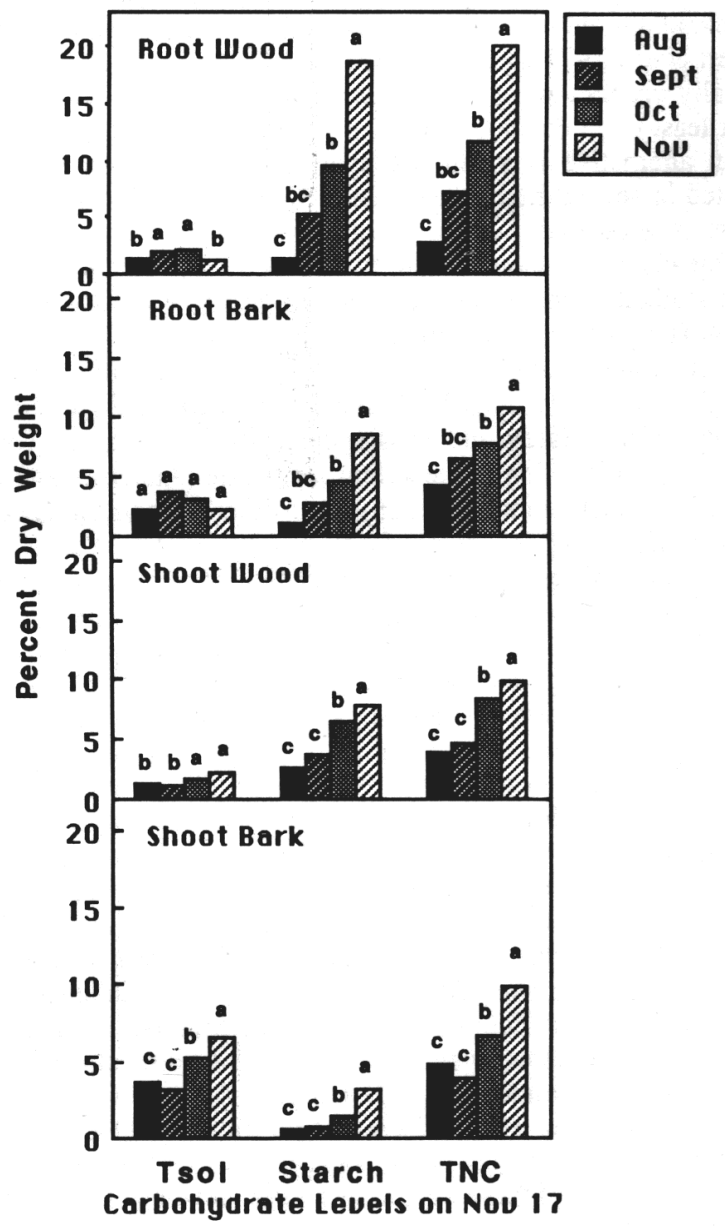

Fig. 3. Defoliation date effect on the major storage carbohydrates in sweet cherry (Prunus avium 'Bing' on 'Mazzard'). Plants were defoliated 4 Aug., 2 Sept., and 2 Oct., with natural leaf abscission in early November. Samples were taken on 17 Nov. 1987. Tsol = total soluble carbohydrates (see Fig. 1 for details), TNC = total nonstructural carbohydrates (see Fig. 1 for details). Letters above the columns designate statistical significance $(P>\mathrm{F}=0.05)$. 
1978b; Hansen and Grauslund, 1973) as well as reserves. Similarly, in sweet cherry pruned to two branches, with one $\left[{ }^{14} \mathrm{C}\right]$-labled and the other unlabeled, although much of the $\left[{ }^{14} \mathrm{C}\right]$-label went to the roots, a considerable amount remained in the leaves, wood, and bark of the labeled branch (McCamant, 1988). Those remaining in the top, however, were removed in sweet cherry by excising the labeled branch after leaf abscission and then following the subsequent appearance in the unlabeled branch of $\left[{ }^{14} \mathrm{C}\right]$-label from root reserves. There was a small amount of $\left[{ }^{14} \mathrm{C}\right]$-label in the unlabeled sweet cherry branch during dormancy, but Priestley (1981) also noted an exchange of carbohydrates between apple roots and shoots during dormancy. At advanced budswell in sweet cherry, label increased only in the buds, as noted by Lockwood and Sparks (1978a, $1978 \mathrm{~b}$ ) in pecan. Also, like pecan, when the first sweet cherry leaves expanded, radioactivity increased in both shoot wood and bark. Although the most $\left[{ }^{14} \mathrm{C}\right]$-label was in recently expanded leaves with less in leaves formed at later dates, cherries clearly use root reserves at budbreak and during early shoot extension.

\section{Transport of root carbohydrate reserves}

If woody plants use root reserves early in the season, before budbreak, how then are carbohydrates translocated acropetally from the roots to the shoots? During the growing season, most carbohydrate translocation occurs within the phloem. Phloem loading is a temperature-dependent, active process, and sieve elements often contain occlusions during the winter. Consequently, there is some question whether the phloem is active in late winter before budbreak (Evert et al., 1972). Nevertheless, some phloem cells do appear functional during dormancy, i.e., a thin layer of sieve tubes nearest the cambium did not contain callose occlusions in their sieve plates (Evert et al., 1972); Fisher (1983) has shown that phloem transport actually occurs during the winter at temperatures as low as -30C in at least three deciduous species (Salix, Tilia, and Acer).

An alternative is xylem transport, which has been well-documented in several herbaceous plants (Andrews, 1986; Pate, 1983). There is good evidence for early season xylem transport in some woody plants. Seasonal changes in xylem sap composition have been studied in many different woody plants, e.g., kiwifruit, Actinidia (Ferguson, 1980), apple (Williams and Raese, 1974), willow (Sauter, 1983; Stanislawek et al., 1987), walnut (Ryugo, 1988), Douglas fir (Pseudotsuga) (Doumas and Zaerr, 1988), and grape (Hardy, 1969; Hardy and Possingham, 1969). Although comprehensive quantification of the xylem sap is rare (Andersen and Brodbeck, 1989), late-winter and early spring increases in solute content are common, and the xylem is clearly an important conduit for translocation of reserve carbohydrates and other materials in grape (Andersen and Brodbeck, 1989), birch (Sauter and Ambrosius, 1986), and willow (Sauter, 1983). Evidence for such transport in tree fruits is limited, although carbohydrate levels in the xylem sap of stone and pome fruits were first investigated by Anderssen (1929); later, Beever (1969) looked at carbohydrates in the xylem sap of fruit trees at budbreak in relation to fungal growth in the wood. There is also evidence for early spring xylem transport associated with hydrolysis of root reserves in apple (Hansen and Grauslund, 1978).

Most evidence for the role of carbohydrates in translocation in xylem sap comes from work on sugar maple, where sucrose levels apparently create the rare phenomenon of positive pressure in the wood, or bleeding sap (Cortes and Sinclair, 1985; Johnson et al., 1987; Milburn and Zimmerman, 1986). In contrast, in grape, positive xylem pressures were closely related to amino and organic acids, and carbohydrates had only a minor role (Andersen and Brodbeck, 1989). Other studies have shown high xylem carbohydrate sap concentrations during winter in species as diverse as apple and willow, but most of these trees do not have bleeding sap. In willow, very high sucrose levels, $3 \%$ to $5 \%(\mathrm{w} / \mathrm{v})$, in the xylem sap occur shortly before bloom (Sauter, 1983; Stanislawek et al., 1988). Similar patterns of high levels of reducing sugars were found in birch (Betula pendula) (Sauter and Ambrosius, 1986). Although much less than in willow or birch, high levels of hexoses (Fig. 4), but not sorbitol or sucrose, were found in sweet cherry sap before bloom (McCamant, 1988). Consistent with other transport phenomena, xylem sap components are apparently actively secreted into the apoplast (Sauter and Kloth, 1987; McCamant, 1988).

If xylem sap is nutritionally significant in species that have only low levels of carbohydrates and other compounds, xylem transport must occur at high rates. Positive xylem pressure may be a factor in some species, but the most likely means of driving transport would be transpiration (Sauter and Ambrosius, 1986). Although transpiration in dormant trees is relatively low, e.g., with a calculated flow of 26 liters.day ${ }^{-1}$ in a 12 -m-tall sugar maple (Milburn and Zimmerman, 1986), a month between the end of low temperatures and the onset of budbreak could account for considerable translocation, especially when considering the high carbohydrate concentrations before budbreak in sugar maple (Cortes and Sinclair, 1985), or even lower concentrations, as in sweet cherry (Beever, 1969; McCamant, 1988). Given the tremendous transpiration potential of a stone fruit tree in full bloom, transport rates after budbreak could be much higher. Birch, which blooms in late winter, clearly transports hexoses in the xylem with a potential of providing nutrients to the developing tissues at rates that equal or exceed those provided through the phloem (Sauter and Ambrosius, 1986).

Following early spring growth demands, xylem solute concentrations usually become much lower during the growing season (Fig. 4), although apple xylem sap has been reported to containe hormones (Luckwill and Whyte, 1968) and low levels of carbohydrates following budbreak (Hansen and Grauslund, 1978). Nonetheless, other data show export in growing woody plants of $\left[{ }^{14} \mathrm{C}\right]$-labeled photosynthates, first to roots presumably as carbohydrates via the phloem and then as amino compounds to mature leaves through the xylem (Bollard, 1960; Dickson, 1979; Kato, 1981). Thus carbon circulates in woody plants much as it does in herbaceous plants (Andrews, 1986; Pate, 1983).

\section{Control of the use of root carbohydrate reserves}

Control of carbohydrate mobilization or use in underground organs such as tubers, roots, and bulbs has been extensively studied only in the tubers of the fructan-storing Jerusalem artichoke (Helianthus tuberosus) and the starch-storing potato (Solanum tuberosum) (Halmer and Bewley, 1982). There are almost no data on control of the use of woody plant root reserves. Signals that control starch hydrolysis have not been considered beyond what controls normal budbreak. In fact, the relationship between starch hydrolysis and dormancy is not always clear (Cottignies, 1986). Gibberellins and cytokinins when sprayed on the tree will cause budbreak, but we do not know if they also directly stimulate starch breakdown. Alpha amylase, an enzyme often stimulated by gibberellins, is normally associated with the rapid breakdown of starch in many plant species, but has only been cursorily studied in woody perennials (Schaefer, 1982; Schaefer and Schwarz, 1986).

Starch hydrolysis in sweet cherry roots appears to be hormonally stimulated (McCamant, 1988). For example, gibberellic acid (GA)

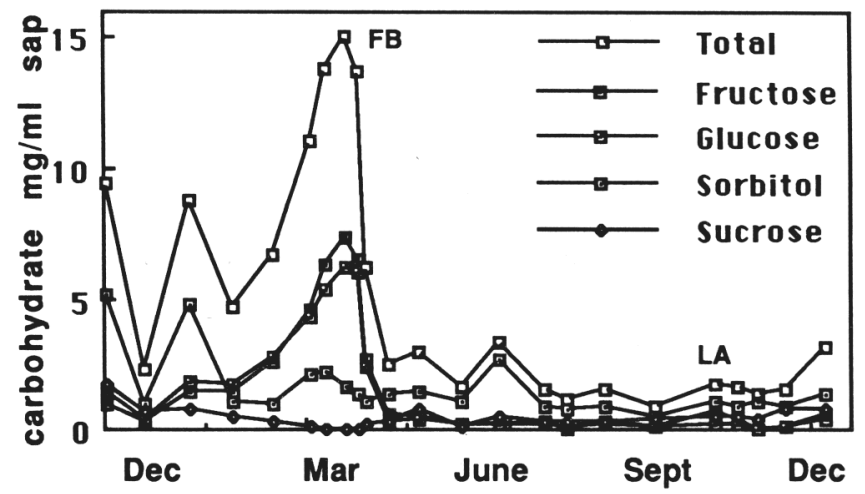

Fig. 4. Soluble carbohydrates found in the first $0.1 \mathrm{ml}$ of xylem sap extracted from primary shoots of sweet cherry (Prunus avium 'Bing' on 'Mazzard') trees, and calculated as total concentration ( $\mathrm{mg} \cdot \mathrm{ml}^{-1}$ of sap). Sampling was from Dec. 1986 through Dec. 1987. FB = full bloom. $\mathrm{LA}=$ leaf abscission 
induced starch hydrolysis in growing roots excised from trees that had not yet begun budswell, but auxin and cytokinin were apparently ineffective. GA also appeared to increase extractable $\alpha-$ amylase activity. Later, following budswell, starch decreased in all starch treatments regardless of the presence or absence of growth regulators; induction had apparently already begun before root excision. Since trees with growing roots did not lose starch, whereas those with growing buds lost starch every time, the stimulus is most likely produced in the buds. Powell (1987) has stated that the rest influence resides in the buds and is transported to the roots. How this stimulus gets to the roots is unknown. A paradox also arises because growing roots are believed to be one of the main sources of gibberellins, while leaf primordia, or the buds, produce auxins (Davies, 1987). Young (1987) suggested that auxins may mediate or start gibberellin production and starch breakdown in apple, but auxins induced no starch hydrolysis in excised cherry roots.

Clearly, resolving the factor(s) involved in the use of root reserves is in the future.

\section{Management effects and implications}

Summer-pruning effects on carbohydrate reserves have long been studied (Winkler, 1929) and can be complex (Saure, 1987). Interpretation is complicated by the same kinds of considerations involved in stress effects. Summer pruning is not the same as defoliation, since the latter predominantly removes photosynthetic sources while the former, by also removing vegetative sinks, redirects allocation. Although summer pruning decreases leaf area and carbon fixation (Mika, 1986; Saure, 1987), it may increase carbohydrate reserves and other compounds in roots and elsewhere, depending on timing.

Fertilizer management effects on reserves are also complex. Nutrient limitations decrease growth, yet commonly result in starch accumulating in many tissues. Roots clearly function as storage organs to include nitrogen reserves in woody perennials (Araujo and Williams, 1988; Faby and Naumann, 1986b, 1986c; Taylor, 1967; Titus and Kang, 1982). Fertilization timing is a major consideration, since root carbohydrate reserves only increase after competition for photosynthates has decreased, e.g., relatively late in a season, or after top and reproductive growth have ceased. Carbohydrate reserves may, for example, be reduced by defoliation and summer pruning and increased by nitrogen fertilizer in the autumn (Tromp, 1983). Presumably, nitrogen prevents onset of dormancy or increases late-season vigor and photosynthesis. Nitrogen assimilation as an energy-dependent process would also depend on the availability of carbohydrates in the roots (Radin et al., 1978), again a late-season phenomenon (see above section on seasonal changes in reserves). This dependency may explain why the main cultural factors that influence nitrogen reserves are not only the amount, but also the time, of nitrogen fertilization (Faby and Naumann, 1985, 1986a, 1986b, 1986c; Tromp, 1983; Weinbaum et al., 1984).

Given that most cultivated deciduous fruit trees are complex genetic systems with rootstocks chosen in many cases for growth control, nutrient uptake characteristics, and, ultimately, such factors as fruit quality and yield efficiency (Westwood, 1978), there is surprisingly little information on root reserves in different rootstocks. Study of rootstock and scion interactions demonstrated that certain rootstocks resulted in greater dry weight of both roots and shoots, but scion effects on the rootstock were complex (Brown et al., 1985). Further work in this area may clarify the role of root reserves in rootstock and scion performance.

\section{SUMMARY}

In the last century, Hartig (1858) proposed that carbohydrates are stored in the roots during winter and move to developing tissues through the wood in the spring. Xylem transport is now accepted as the major pathway for movement from roots to shoot in most higher plants, although the data are somewhat limited for fruit trees and many other woody species. Root reserves not only occur in concentrations higher than in other tissues, but are also very sensitive to defoliation and other disruptions of photosynthesis, particularly late in the season following cessation of vegetative growth. Root reserves have a role as an important and perhaps the major source of substrates for the subsequent year's early respiration, growth, and development. The sensitivity of root reserves to late-season stresses may disproportionately affect plant performance and yield, particularly for early flowering and fruiting. The implications of these and other roles of root reserves, their effects on nutrient uptake and assimilation, control of their use and transport, and the specific effects of management practices, are only beginning to be realized.

\section{Literature Cited}

Abusrewil, G.S., F.E. Larsen, and R. Fritts, Jr. 1983. Prestorage and poststorage starch levels in chemically and hand-defoliated 'Delicious' apple nursery stock. J. Amer. Soc. Hort. Sci. 108:20-23.

Andersen, P.C. and B.V. Brodbeck. 1989. Diurnal and temporal changes in the chemical profile of xylem exudate from Vitis rotundifolia. Physiol. Plant. 75:63-70.

Anderson, A.G. and H.D. Hooker. 1927. Soil treatments and seasonal chemical changes in the sour cherry. Missouri Agr. Expt. Sta. Res. Bul. 108 .

Anderssen, F.G. 1929. Some seasonal changes in the tracheal sap of pear and apricot trees. Plant Physiol. 4:456-459.

Andrews, M. 1986. The partitioning of nitrate assimilation between root and shoot of higher plants. Plant, Cell Environ. 9:511-519.

Araujo, F.J. and L.E. Williams. 1988. Dry matter and nitrogen partitioning and root growth of young field-grown 'Thompson Seedless' grapevines. Vitis 27:21-32.

Archer, C.J. 1941. The starch cycle in the Hachiya persimmon. Proc. Amer. Soc. Hort. Sci. 38:187-190.

Bains, K.S., A.S. Bindra, and J.S. Bal. 1981. Seasonal changes in carbohydrate and mineral composition of overvigorous and devitalized Anabe-Shahi grapevines in relation to unfruitfulness. Vitis 20:311-319.

Beattie, J.M. 1948. Carbohydrates in apple shoots and twigs and their relation to nitrogen fertilization. yield. and fruit color. Proc. Amer. Soc. Hort. Sci. 51:33-40.

Beever, D.J. 1969. The relationship between nutrients in extracted xylem sap and the susceptibility of fruit trees to silver-leaf disease caused by Stereum purpureum (Pers.) Fr. Ann. Applied Biol. 65:93-103.

Beres, V. 1972. Seasonal occurrence and function of sorbitol, sucrose, glucose, and fructose in various tissues of cherry. PhD Diss., Univ. of California, Davis. [Diss. Abstr. 73-8310.]

Bollard, E.G. 1960. Transport in the xylem. Annu. Rev. Plant Physiol. 11:141-166.

Bonicel, A., G. Haddad, and J. Gagnaire. 1987. Seasonal variations of starch and major soluble sugars in the different organs of young poplars. Plant Physiol. Biochem. 25:451-459.

Bradford, K.J. and T.C. Hsiao. 1982. Physiological responses to moderate water stress, p. 263-324. In: O.L. Lange, P.S. Nobel, C.B. Osmond, and H. Ziegler (eds.). Encycl. Plant Physiol., N.S., vol. 12B Physiological plant ecology II. Water relations and carbon assimilation. SpringerVerlag, New York.

Braun, J.W., A.W. Helton, and D. LeTourneau. 1971. Soluble carbohydrates in bark of Italian prune (Prunus domestica) trees. Physiol. Plant. 24:1214-217.

Breen, P.J. 1975. Effect of peach/plum graft incompatibility on seasonal carbohydrate changes. J. Amer. Soc. Hort. Sci. 100:253-259.

Brown, C.S., E. Young, and D.M. Pharr. 1985. Rootstock and scion effects on the seasonal distribution of dry weight and carbohydrates in young apple trees. J. Amer. Soc. Hort. Sci. 110:696-701

Cameron, S.H. 1923. Storage of starch in the pear and apricot. Proc. Amer. Soc. Hort. Sci. 20:98-100.

Cannell, M.G.R. 1985. Dry matter partitioning in tree crops, p. 160-193. In: M.G.R. Cannell and J.E. Jackson (eds.). Attributes of trees as crop plants, Inst. Terrestrial Ecology, Huntingdon, England.

Chong, C. 1971. Study of the seasonal and daily distribution of sorbitol and related carbohydrates within apple seedlings by analysis of selected tissues and organs. Can. J. Plant Sci. 51:519-525.

Chong, C. and C.D. Taper. 1971a. Daily variation of sorbitol and related carbohydrates in Malus leaves. Can. J. Bot. 49:173-177.

Chong, C. and C.D. Taper. 1971b. Effect of solar radiation on seasonal concentrations of sorbitol and related carbohydrates in apple leaves. Can. J. Plant Sci. 51:551-553.

Cortes, P.M. and T.R. Sinclair. 1985. The role of osmotic potential in spring sap flow of mature sugar maple trees (Acer saccharum Marsh). J. Expt. Bot. 36:12-24.

Cottignies, A. 1986. The hydrolysis of starch as related to the interruption of dormancy in the ash bud. J. Plant Physiol. 123:381-388.

Crane, J.C. and I. Al-Shalan. 1977. Carbohydrates and nitrogen levels in pistachio branches as related to shoot extension and yield. J. Amer. Soc. Hort. Sci. 102:396-399. 
Crane, J.C., P.B. Catlin, and I. Al-Shalan. 1976. Carbohydrate levels in the pistachio as related to alternate bearing. J. Amer. Soc. Hort. Sci. 101:371-374

Davies, P.J. 1987. The plant hormones; their nature, occurrence and functions, p. 1-11. In: P.J. Davies (ed.). Plant hormones and their role in plant growth and development. Martinus Nijhoff, Boston.

Davis, T.J. and D. Sparks. 1974. Assimilation and translocation patterns of carbon-14 in the shoot of fruiting pecan trees, Carya illinoiensis. J. Amer. Soc. Hort. Sci. 99:468-480.

Davis, L.D. 1931. Some carbohydrate and nitrogen constituents of alternatebearing sugar prunes associated with fruit bud formation. Hilgardia 5:119 154.

De Villiers, O.T. and J.T. Meynhardt. 1972. Seasonal changes in sorbitol and sugars in Santa Rosa plums. Agroplantae 4:93-96.

Dickson, R.E. 1979. Xylem translocation of amino acids from roots to shoots in cottonwood plants. Can. J. For. Res. 9:374-378.

Doumas, P. and J.B. Zaerr. 1988. Seasonal changes in levels of cytokininlike compounds from Douglas-fir xylem extrudate. Tree Physiol. 4:1-8.

Dowler, W.M. and F.D. King. 1966. Seasonal changes in starch and soluble sugar content of dormant peach tissues. Proc. Amer. Soc. Hort. Sci. 89:80-84.

Eifert, J. and A. Eifert. 1963. Maximum of starch during spring in the woody plant (Vitis riparia Michx.). Nature (London) 199:825-826.

Evert, R.F., T.T. Kozlowski, and J.D. Davis. 1972. Influence of phloem blockage on cambial growth of sugar maple. Amer. J. Bot. 59:632-641.

Faby, R. and W.-D. Naumann. 1985. The influence of N-reserves in the trees on the generative performance of young apple trees: I. Incorporation and mobilization of N-reserve in bark and wood. Angew. Botanik 59:367392

Faby, R. and W.-D. Naumann. 1986a. The influence of N-reserves in the trees on the generative performance of young apple trees: II. Generative performance. Angew. Botanik 60:7-21.

Faby, R., and W.-D. Naumann. 1986b. Effects of defoliation of apple trees after harvest: I. Incorporation and mobilization of nitrogenous reserves. Gartenbauwissenschaft 51:69-75.

Faby, R. and W.-D. Naumann. 1986c. Effects of defoliation of apple trees after harvest. II. Mineral and carbohydrate contents in shoots, crop yield. Gartenbauwissenschaft 51:136-142.

Ferguson. A.R. 1980. Xylem sap from Actinidia chinensis: apparent differences in sap composition arising from methods of collection. Ann. Bot. 46:791-801.

Fischer, W. 1891. Beitrage zur Physiologie der Holzgewächse. Jahrb. Wiss. Bot. 74:457-696.

Fisher, D.B. 1983. Year-round collection of willow sieve-tube exudate. Planta 159:529-533.

Fowells, H.A. 1965. Silvics of forest trees of the United States. USDA Agr. Hdbk. 271.

Fry, S.C. 1986. Cross-linking of matrix polymers in the growing cell walls of angiosperms. Annu. Rev. Plant Physiol 37:165-186.

Gardner, F.E. 1929. Composition and growth initiation of Bartlett pear shoots as influenced by temperature. Plant Physiol. 4:405-434.

Glerum, C. 1980. Food sinks and food reserves of trees in temperate climates. New Zealand J. For. Sci. 10:176-185.

Goldschmidt, E.E. and A. Golomb. 1982. The carbohydrate balance of alternate-bearing citrus trees and the significance of reserves for flowering and fruiting. J. Amer. Soc. Hort. Sci. 107:206-208.

Gregory, R.A. and P.M. Wargo. 1986. Timing of defoliation and its effect on bud development, starch reserves, and sap sugar concentration in sugar maple. Can. J. For. Res. 16:10-17.

Grochowska, M.J. 1973. Comparative studies on physiological and morphological features of bearing and non-bearing spurs of the apple tree. I. Changes in starch content during growth. J. Hort. Sci. 48:347-356.

Hale, C.R. and R.V. Weaver. 1962. The effect of developmental stage on direction of translocation of photosynthate in Vitis vinifera. Hilgardia 33:89-131.

Halmer, P. and J.D. Bewley. 1982. Control by external and internal factors over the mobilization of reserve carbohydrates in higher plants, p. 748 793. In: F.A. Loewus and W. Tanner (eds.). Encycl. Plant Physiol., New Ser., vol. 13A, Springer-Verlag, Berlin.

Hansen, P. 1967. ${ }^{14} \mathrm{C}$-studies on apple trees: III. The influence of season on storage and mobilization of labelled compounds. Physiol. Plant. 20:11031111.

Hansen, P. 1971. ${ }^{14} \mathrm{C}$-studies on apple trees: VII. The early seasonal growth in leaves, flowers, and shoots as dependent upon current photosynthesis and existing reserves. Physiol. Plant. 25:469-473.

Hansen, P. and J. Grauslund. 1973. ${ }^{14} \mathrm{C}$-studies on apple trees.: VIII. The seasonal variation and nature of reserves. Physiol. Plant. 28:24-32.

Hansen, P. and J. Grauslund. 1978. Levels of sorbitol in bleeding sap and in xylem sap in relation to leaf mass and assimilate demand in apple trees. Physiol. Plant. 42:129-133.
Hardy, P.J. 1969. Selective diffusion of basic and acidic products of $\mathrm{CO}_{2}$ fixation into the transpiration stream of grapevines. J. Expt. Bot. 20:856862.

Hardy, P.J. and J.V. Possingham. 1969. Studies on translocation of metabolites in the xylem of grapevine shoots. J. Expt. Bot. 20:325-335.

Hartig. T. 1858. Über die Bewegung des Saftes in Holzpflanzen. Bot. Zeit. $16: 329-342$

Head, G.C. 1969. The effects of fruiting and defoliation on seasonal trends in new root production on apple trees. J. Hort. Sci. 44:175-181.

Hooker, H.D., Jr. 1920. Seasonal changes in the chemical composition of apple spurs. Missouri Agr. Expt. Sta. Res. Bul. 40.

Ichiki, S. and H. Yamaya. 1982. Sorbitol in tracheal sap of dormant apple (Malus domestica Borkh.) shoots as related to cold hardiness, p. 181187. In: P.H. Li and A. Sakai (eds.). Plant cold hardiness and freezing stress, vol. 2. Academic, New York.

Isebrands, J.G. and N.D. Nelson. 1983. Distribution of $\left[{ }^{14} \mathrm{C}\right]$-labeled photosynthates within intensively cultured Populus clones during the establishment year. Physiol. Plant. 59:9-18.

Johnson, R.W., M.T. Tyree, and M.A. Dixon. 1987. A requirement for sucrose in xylem sap flow from dormant maple trees. Plant Physiol. 84:495-500.

Jones, W.W., T.W. Embleton, M.L. Steinacker, and C.B. Cree. 1970. Carbohydrates and fruiting of 'Valencia' orange trees. J. Amer. Soc. Hort. Sci. 95:380-381.

Kandiah, S. 1979a. Turnover of carbohydrates in relation to growth in apple trees: I. Seasonal variation of growth and carbohydrate resources. Ann. Bot. 44:175-183.

Kandiah, S. 1979b. Turnover of carbohydrates in relation to growth in apple trees: II. Distribution of ${ }^{14} \mathrm{C}$-assimilates labelled in autumn, spring and summer. Ann. Bot. 44:185-195.

Kato, T. 1981. Major nitrogen compounds transported in xylem vessels from roots to top in citrus trees. Physiol. Plant. 52:275-279.

Keller, J.D. and W.H. Loescher. 1989. Nonstructural carbohydrate partitioning in perennial parts of sweet cherry. J. Amer. Soc. Hort. Sci. 114:969975.

Kliewer, W.M. 1965. The sugars of grapevines. II. Identification and seasonal changes in the concentration of several trace sugars in Vitis vinifera. Amer. J. Enol. Viticult. 16:168-178.

Kliewer, W.M. 1967. Annual cyclic changes in the concentration of sugars and organic acids in 'Thompson Seedless' grapevines. Proc. Amer. Soc. Hort. Sci. 91:205-212.

Kliewer, W.M. and A.R. Nassar. 1966. Changes in concentration of organic acids, sugars, and amino acids in grape leaves. Amer. J. Enol. Viticult. 17:48-57.

Kramer, P.J. and T.T. Kozlowski. 1979. Physiology of woody plants. Academic, New York.

Lasheen, A.M. and C.E. Chaplin. 1977. Seasonal sugar concentration in two peach cultivars differing in cold hardiness. J. Amer. Soc. Hort. Sci. 102:171-174

Lenz, F. and U. Küntzel. 1974. Carbohydrate content of citrus leaves as affected by fruit load. Gartenbauwissenschaft 39:99-101.

Lewis, D.H. 1984. Physiology and metabolism of alditols, p. 157-179. In: D.H. Lewis (ed.). Storage carbohydrates in vascular plants. Cambridge Univ. Press, Cambridge, U.K.

Lockwood, D.W. and D. Sparks. 1978a. Translocation of ${ }^{14} \mathrm{C}$ in 'Stuart' pecan in the spring following assimilation of ${ }^{14} \mathrm{CO}_{2}$ during the previous growing season. J. Amer. Soc. Hort. Sci. 103:38-45.

Lockwood. D.W. and D. Sparks. 1978b. Translocation of ${ }^{14} \mathrm{C}$ from tops and roots of pecan in the spring following assimilation of ${ }^{14} \mathrm{CO}_{2}$ during the previous growing season. J. Amer. Soc. Hort. Sci. 103:45-49.

Loescher, W.H. 1987. Physiology and metabolism of sugar alcohols in higher plants. Physiol. Plant. 70:553-557.

Loescher. W.H., G.C. Marlow, and R.A. Kennedy. 1982. Sorbitol metabolism and sink-source interconversions in developing apple leaves. Plant Physiol. 70:335-339.

Luckwill, L.C. and P. Whyte. 1968. Hormones in the xylem sap of apple trees. Soc. Chem. Ind. Monogr. 31:87-101.

McCamant, T. 1988. Utilization and transport of storage carbohydrates in sweet cherry. MS Thesis, Washington State Univ., Pullman.

Marutyan, S.A. 1962. Transformation of carbohydrates in the roots of grape shoots induced by cold. Sov. Plant Physiol. 9:196-197.

Mika, A. 1986. Physiological responses of fruit trees to pruning. Hort. Rev. 8:337-378

Milburn, J.A. and M.H. Zimmerman. 1986. Sapflow in the sugar maple in the leafless state. J. Plant Physiol. 124:331-344.

Mochizuki, T. and S. Hanada. 1956. The seasonal changes of the constituents of young apple trees (part 1) total sugars and starch. Soil Plant Food $2: 115-122$.

Murneek, A.E. 1933. Carbohydrate storage in apple trees. Proc. Amer. Soc. Hort. Sci. 30:319-321. 
Nelson, E.A. and R.E. Dickson. 1981. Accumulation of food reserves in cottonwood stems during dormancy induction. Can. J. For. Res. 11:145154.

Olofinboba, M.O. 1969. Seasonal variation in the carbohydrates in the xylem of Antiaris africana. Ann. Bot. 33:339-349.

Opler. P.A., G.W. Frankie and H.G. Baker. 1976. Rainfall as a factor in the release, timing, and synchronization of anthesis by tropical trees and shrubs. J. Biogeogr. 3:231-236.

Pate, J.S. 1983. Distribution of metabolites, p. 335-401. In: F.C. Steward (ed.). Plant physiology. vol. VIII. Nitrogen metabolism. Academic, NY

Pickett, T.A. and F.F. Cowart. 1941. Carbohydrate changes in muscadine grape shoots during the growing season. Proc. Amer. Soc. Hort. Sci. 38:393-394.

Pollock, C.J. 1986. Fructans and the metabolism of sucrose in vascular plants. New Phytol. 104:1-24.

Powell, L.E. 1987. The hormonal control of bud and seed dormancy in woody plants, p. 539-552. In: P.J. Davies (ed.). Plant hormones and their role in plant growth and development. Martin Nijhoff, Boston.

Priestley, C.A. 1960. Seasonal changes in the carbohydrate resources of some six-year-old apple trees. Annu. Rept. E. Malling Res. Sta. 1959. p. 70-77.

Priestley, C.A. 1962. Carbohydrate resources within the perennial plant. Commonw. Bur. Hort. Plantation Crops, East Malling, Great Britain. Tech. Commun. 27.

Priestley, C.A. 1964. The location of carbohydrate resources within the apple tree. Proc. XVI Intl. Hort. Congr., 1962. 3:319-327.

Priestley, C.A. 1981. Perennation in woody fruit plants and its relationship to carbohydrate turnover. Ann. Applied Biol. 98:548-552.

Proebsting, E.L. 1925. The relation of stored food to cambial activity in the apple. Hilgardia 1:81-106.

Quinlan, J.D. 1969. Mobilization of ${ }^{14} \mathrm{C}$ in the spring following autumn assimilation of ${ }^{14} \mathrm{CO}_{2}$ by an apple rootstock. J. Hort. Sci. 44:107-110.

Radin, J.W., L.L. Parker, and C.R. Sell. 1978. Partitioning of sugar between growth and nitrate reduction in cotton roots. Plant Physiol. 62:550553.

Raese, J.T., M.W. Williams, and H.D. Billingsley. 1978. Cold hardiness, sorbitol, and sugar levels of apple shoots as influenced by controlled temperatures and season. J. Amer. Soc. Hort. Sci. 103:796-801.

Rao, Y.V. and W.E. Berry. 1940. The carbohydrate relations of a single scion variety grafted on Malling rootstocks IX and XIII. A contribution to the physiology of dwarfing. J. Pomol. Hort. Sci. 18:193-225.

ap Rees, T. 1984. Sucrose metabolism, p. 53-73. In: D.H. Lewis (ed.). Storage carbohydrates in vascular plants. Cambridge Univ. Press, Cambridge, U.K.

Rohrback, K.G. and N.S. Luepschen. 1968. Seasonal changes in sugar alcohols and sugars in peach bark: a possible relationship to Cytospora canker susceptibility. Proc. Amer. Soc. Hort. Sci. 93:135-140.

Rom, C.R. and D.C. Ferree. 1985. Time and severity of summer pruning influences on young peach tree net photosynthesis, transpiration, and dry weight distribution. J. Amer. Soc. Hort. Sci. 110:455-461.

Roper, T.R., J.D. Keller, W.H. Loescher, and C.R. Rom. 1988. Photosynthesis and carbohydrate partitioning in sweet cherry: Fruiting effects. Physiol. Plant. 72:42-47.

Ryugo, K. 1988. Fruit culture, its science and art. Wiley, New York

Ryugo, K. and L.D. Davis. 1959. The effect of time of ripening on the starch content of bearing peach branches. Proc. Amer. Soc. Hort. Sci. 74:130-133.

Ryugo, K., B. Marangoni, and D.E. Ramos. 1980. Light intensity and fruiting effects on carbohydrate contents, spur development, and return bloom of 'Hartley' walnut. J. Amer. Soc. Hort. Sci. 105:223-227.

Ryugo, K., N. Nii, M. Iwata, and R.M. Carlson. 1977. The effect of fruiting on carbohydrate and mineral composition of stems and leaves of French prunes. J. Amer. Soc. Hort. Sci. 102:813-816.

Saure, M. 1987. Summer pruning effects in apple-a review. Scientia Hort. 30:253-282.

Sauter, J.J. 1983. Efflux and reabsorption of sugars in the xylem: II. Seasonal changes in sucrose uptake in Salix. Z. Pflanzenphysiol. 111:429440.

Sauter, J.J. 1988. Temperature-induced changes in starch and sugars in the stem of Populus x canadensis 'Robusta.' J. Plant Physiol. 132:608-612.

Sauter, J.J. and T. Ambrosius. 1986. Changes in the partitioning of carbohydrates in the wood during bud break in Betula pendula Roth. J. Plant Physiol. 124:31-43.

Sauter, J.J. and S. Kloth. 1987. Changes in carbohydrates and ultrastructure in xylem ray cells of Populus in response to chilling. Protoplasma 137:4555.

Sauter, J.J., B. van Cleve, and K. Apel. 1988. Protein bodies in ray cells of Populus xcanadensis Moench 'Robusta.' Planta 173:31-34.

Schaefer, H. 1982. Extraction of proteins and enzymes from fruit tree tissues. Gartenbauwissenschaft 47:35-41.
Schaefer, H. and K.G. Schwartz. 1986. Jahreszeitliche bedingte Veränderung im Kohlenhydratstoffwechsel und im Auftreten der Phosphorylase und sauren Phosphatase bei zwei Apfelsorten. Gartenbauwissenschaft 51:165-170.

Scholefield, P.B., T.F. Neales, and P. May. 1978. Carbon balance of the Sultana vine (Vitis vinifera L.) and the effects of autumn defoliation by harvest-pruning. Austral. J. Plant Physiol 5:561-570.

Seybold, S. 1969. Zum jahres-und tagesperiodischen Verhalten von Zuckeralkoholen in vegetativen Pflanzenteilen. Flora 160:561-575.

Smith, C.L. and J.G. Waugh. 1938. Seasonal variations in the carbohydrate and nitrogen content of roots of bearing pecan trees. J. Agr. Res. 57:449460

Smith, C.L., J. Hamilton, C.J.B. Thor, and L.D. Romberg, 1939. Root composition and top development in large pecan trees headed to various degrees of severity in top working. J. Agr. Res. 58:821-842.

Smith, M.W., R.W. McNew, P.L. Ager, and B.C. Cotten, 1986. Seasonal changes in the carbohydrate concentration in pecan shoots and their relationship to flowering. J. Amer. Soc. Hort. Sci. 111:558-561.

Stanislawek, S.D., P.G. Long, and L.K. Davis. 1987. Sugar content of xylem sap and susceptibility of willow to Chondrostereum purpureum. New Zealand J. Bot. 25:263-269.

Stassen, P.J.C., D.K. Strydom, and H.W. Stindt. 1981. Seasonal changes in carbohydrate fractions of young Kakamas peach trees. Agroplantae 13:47-53.

Taper, C.D. and P.S. Liu. 1969. Sorbitol occurrence in Malus leaves and fruits. Can. J. Plant Sci. 49:97-98.

Taylor, B.K. 1967. Storage and mobilization of nitrogen in fruit trees: A review. J. Austral. Inst. Agr. Sci. 33:23-29.

Titus, J.S. and S.M. Kang. 1982. Nitrogen metabolism, translocation, and recycling in apple trees. Hort. Rev. 4:204-246.

Traub, H.P. 1927. Regional and seasonal distribution of moisture, carbohydrates, nitrogen, and ash in 2-3 year portions of apple twigs. Univ. Minn. Agr. Expt. Sta. Res. Bul. 53.

Tromp, J. 1983. Nutrient reserves in roots of fruit trees, in particular carbohydrates and nitrogen. Plant \& Soil 71:401-413.

Tromp, J. and J.C. Ovaa. 1984. Effect of root temperature on the aminonitrogen composition of leaves in successive segments of apple shoots. Physiol. Plant. 62:209-214.

Wagner, M.R. and P.D. Evans. 1985. Defoliation increases nutritional quality and allelochemics of pine seedlings. Oecologia 67:235-237.

Wargo, P.M. 1979. Starch storage and radial growth in woody roots of sugar maple. Can. J. For. Res. 9:49-56.

Waring, R.H. 1987. Characteristics of trees predisposed to die. Bioscience 37:569-574.

Weinbaum, S.A., I. Klein, F.E. Broadbent, W.C. Micke, and T.T. Muraoka. 1984. Effects of time of nitrogen application and soil texture on the availability of isotopically labeled fertilizer nitrogen to reproductive and vegetative tissue of mature almond trees. J. Amer. Soc. Hort. Sci. 109:339-343

Westwood, M.N. 1978. Temperate-zone pomology. Freeman, San Francisco.

Whetter, J.M. and C.D. Taper. 1963. Seasonal occurrence of sorbitol (Dglucitol) in buds and leaves of Malus. Can. J. Bot. 41:175-177.

Williams, M.W. and J.T. Raese. 1974. Sorbitol in tracheal sap of apple as related to temperature. Physiol. Plant. 30:49-52.

Winkler, A.J. 1929. The effect of dormant pruning on the carbohydrate metabolism of Vitis vinifera. Hilgardia 4:153-173.

Winkler, A.J. and W.O. Williams. 1938. Carbohydrate metabolism of Vitis vinifera: hemicellulose. Plant Physiol. 13:381-390.

Winkler, A.J. and W.O. Williams. 1945. Starch and sugars of Vitis vinifera. Plant Physiol. 20:412-432.

Winkler, A.J., J.A. Cook, W.M. Kliewer, and L.A. Lider. 1974. General viticulture. Univ. of Calif. Press, Berkeley.

Wood, B.W. and J.L. McMeans. 1981. Carbohydrate changes in various organs of bearing and nonbearing pecan trees. J. Amer. Soc. Hort. Sci. 106:758-761.

Worley, R.E. 1973. Pecan nutlet set and carbohydrate level of various tissues in the spring as affected by fungicide sprays. J. Amer. Soc. Hort. Sci. 98:758-761

Worley, R.E. 1979. Fall defoliation date and seasonal carbohydrate concentration of pecan wood tissue. J. Amer. Soc. Hort. Sci. 104:195-199.

Yamashita, T. 1984. Changes in the content of amino acids, carbohydrates and adenine nucleotides following budding in the hardwood stems of mulberry plants (Morus alba). Ann. Bot. 54:283-288.

Yamashita, T. 1986. Mobilization of carbohydrates, amino acids and adenine nucleotides in hardwood stems during regrowth after partial shoot harvest in mulberry trees (Morus alba L.). Ann. Bot. 57:237-244.

Young, E. 1987. Effects of 6-BA, $\mathrm{GA}_{4+7}$, and IBA on growth resumption of chilled apple roots and shoots. HortScience 22:212-213. 